Table 1. Fresh Whights of SeEdings grown From Fumigated AND UNFUMIGated SEed OF DiFferent MolstuRE CONTENTS

\begin{tabular}{|c|c|c|c|c|}
\hline \multirow{3}{*}{$\begin{array}{c}\text { Fresh } \\
\text { weight } \\
\text { (gm.) }\end{array}$} & \multicolumn{4}{|c|}{ Number of plants } \\
\hline & \multicolumn{2}{|c|}{10 per cent moisture } & \multicolumn{2}{|c|}{12 per cent moisture } \\
\hline & Control & Treated & Control & Treated \\
\hline $\begin{array}{c}0 \cdot 0-0 \cdot 2 \\
0 \cdot 3-0 \cdot 5 \\
0 \cdot 6-0 \cdot 8 \\
0 \cdot 9-1 \cdot 1 \\
1 \cdot 2-1 \cdot 4 \\
1 \cdot 5-1 \cdot 7 \\
1 \cdot 8-2 \cdot 0 \\
>2 \cdot 1\end{array}$ & $\begin{array}{r}- \\
1 \\
1 \\
6 \\
10 \\
5 \\
4 \\
3\end{array}$ & $\begin{array}{l}1 \\
5 \\
4 \\
5 \\
6 \\
1 \\
2 \\
4\end{array}$ & $\begin{array}{r}1 \\
1 \\
2 \\
1 \\
7 \\
2 \\
4 \\
12\end{array}$ & $\begin{array}{r}7 \\
1 \\
0 \\
1 \\
2 \\
3 \\
3 \\
3 \\
10\end{array}$ \\
\hline Total & 30 & 28 & $\overline{30}$ & 27 \\
\hline
\end{tabular}

moisture content did not appear to suffer so drastically from fumigation though their general growth was retarded.

It seems likely from work still in progress that the retardation of growth in seedlings from seeds with the lower moisture content is only temporary and will not affect the ultimate yield. However, the severe retardation observed for about a quarter of the plants grown from the moister seeds that had been fumigated is likely to be permanent, the seedlings being deformed and only slowly, if ever, reaching maturity.

The above results stress the need for measuring growth and yield as well as germination when considering the effect of fumigants on stored seed to be used for planting.

Department of Agriculture,

G. H. Caswell

H. T. CllFFord

University College,

Ibadan, Nigeria. June 14.

${ }^{2}$ Alexander, F. E. S., and Clifford, H. T., Nature, 179, 109 (1957).

\section{An Age Effect on Seta Elongation in Pellia epiphylla}

Is a recent communication, Asprey et al. ${ }^{1}$ report that spraying with indolylacetic acid and gibberellin effects elongation of the setæ of Pellia epiphylla in January, whereas under normal conditions this is delayed until late February or early March. We have obtained results which suggest that during the winter months a gradual change occurs, bringing setæ into a condition when they are capable of rapid elongation once the temperature is raised. In view of the results of Asprey et al., this internal change may well be correlated with synthesis of growth hormones.

Table 1. EfFects of Age, Rise in Tamperature and Extra light ON SETA ElONGATION

Time (weeks) from collecting material until 50 per cent of the setae started to elongate

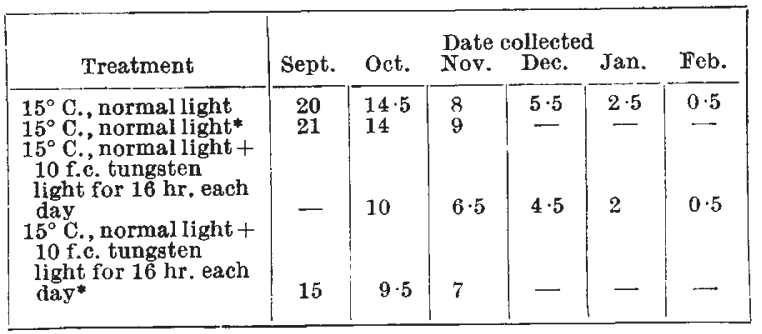

* Kept 2 weeks at $1^{\circ} \mathrm{C}$. immediately after collection.

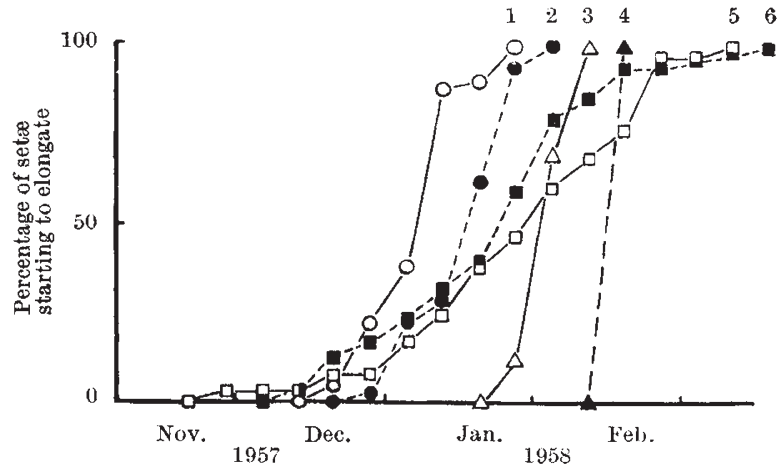

Fig. 1. Effect of age on the ability of setæ to elongate when transferred to $15^{\circ} \mathbf{C}$. Material in the field showed no seta 2, December; 3, January ; 4, February ; 5, September; 6 , October

Fresh material of Pellia epiphylla was collected from a site near Southampton at intervals from mid-September 1957 to February 1958 and kept in a warm greenhouse (mean temperature $15^{\circ} \mathrm{C}$, minimum $10^{\circ} \mathrm{C}$.). The number of setæ elongating was counted at weekly intervals and the capsule contents also examined. Fig. 1 shows that rise in temperature promotes seta elongation in every case (material left in the field did not start to elongate until March 1958), but the most marked effect is that of age of the sporophyte. This is shown more clearly in Table 1, which records the lag period before 50 per cent of the setæ start to elongate. Two weeks cold treatment $\left(1^{\circ} \mathrm{C}\right.$.) given immediately after material had been collected did not affect the results, but provision of extra light shortened the lag period slightly. It is tentatively suggested that during the winter there is a slow synthesis of growth hormones (or removal of a growth inhibitor), which is stimulated to some extent by a rise in temperature and extra light. The fact that the maximum length reached by setæ was considerably less in samples collected early in the season would also support this idea. It would be of particular interest to know if indolylacetic acid and gibberellin are effective in promoting seta elongation in material collected in the autumn.

Subsidiary observations were made on spore development, since it has been suggested that maturation of the spores is the stimulus for seta elongation. Under normal conditions the tetrads divide into spores at the end of November, but material collected in September and October before this change had occurred and kept at a warm temperature, had not formed spores by March 1958, when observations were discontinued. Despite immaturity of the spores seta elongation occurred (Table 1), and it is therefore highly improbable that there is a direct relationship between spore maturation and seta elongation. A similar conclusion was reached by Asprey et al. from their experiments. A further observation supporting this was that two weeks cold treatment was effective in stimulating tetrad division in material collected in October, but seta elongation was unaffected.

\section{W. Mary Cromble} JeAN A. Paton

Botany Department,

University of Southampton. June 27.

${ }^{1}$ Asprey, G. F., Benson-Evans, K., and Lyon, A. G.. Nature, 181, 